\title{
Immune functions in beluga whales (Delphinapterus leucas): evaluation of natural killer cell activity
}

\author{
Sylvain De Guise ${ }^{1, a, b, *}$, Peter S. Ross ${ }^{c}$, A.D.M.E. Osterhaus ${ }^{\mathrm{d}}$, \\ Daniel Martineau ${ }^{\mathrm{e}}$, Pierre Béland ${ }^{\mathrm{b}}$, Michel Fournier ${ }^{\mathrm{a}}$ \\ a TOXEN, Université du Québec à Montréal, C.P. 8888, Succ. A, Montréal Qué.. Canada H3C 3P8 \\ ${ }^{\mathrm{h}}$ St. Lawrence National Institute of Ecotoxicology, 460 Champ-de-Mars, \# 504, Montréal Qué.. \\ Canada $\mathrm{H} 2 \mathrm{Y} 1 \mathrm{~B} 4$ \\ "Seat Rehabilitation and Research Center, 9968 AG Pieterburen. Netherlands \\ ${ }^{\circ}$ Erasmus University Rotterdam, Department of Virologv, P.O. Box 1738, 3000 DR Rotterdam, Netherlands \\ ' Faculté de Médecine Vétérinaire, Université de Montréal, C.P. 5000, St-Hvacinthe Qué.. Canada J2S 7CG
}

Received in revised form 18 February 1997; accepted 4 March 1997

\begin{abstract}
Natural killer (NK) activity, an important non-specific defense mechanism against viral infections and tumors, was demonstrated in beluga whales using two different methods: ${ }^{51} \mathrm{Cr}$ release and flow cytometry. Using the ${ }^{5 \mathrm{C}} \mathrm{Cr}$ release assay, $\mathrm{NK}$ activity in belugas was shown to be higher against K-562 than against $\mathrm{YAC}-1$ cell lines. Moreover, it was enhanced by the addition of human recombinant interleukin-2 with both cell lines. NK activity evaluated by flow cytometry in the peripheral blood of eight belugas increased when the effector:target cell (E:T) ratio increased, and averaged $13.9 \% \pm 3.8 \%$ (range $9.9 \%$ to $17.8 \%$ ) at an E:T ratio of $100: 1$. While NK activity could be readily detected using both methods, the lack of radio-isotopes and related laboratory room make the flow cytometric method a viable and safe alternative. The evaluation of this function in cetaceans could lead to a hetter understanding of the early events that lead to viral epizootics in populations of marine mammals in different parts of the world, as well as to the high prevalence of neoplasms in St. Lawrence beluga whales. (C) 1997 Elsevier Science B.V.
\end{abstract}

Kevwords: NK activity: Beluga whale; Cetacean: Delphinapterus leucas

\footnotetext{
* Corresponding author. Tel.: + 1-916-752-7187; fax: + 1-916-752-3349.

${ }^{1}$ Current address Department of Pathology, Microbiology and Immunology. School of Veterinary Medicine. University of California Davis. Davis CA 95616, USA.
} 


\section{Introduction}

Natural killer (NK) cells represent a heterogeneous population of CD3 negative, T-cell receptor negative, large granular lymphocytes that commonly express surface markers such as CD16 and CD56 in humans (O'Shea and Ortaldo, 1992). NK activity, which is mainly directed against tumor cells (O'Shea and Ortaldo, 1992) and virus-infected cells (Biron and Welsh, 1982, Welsh et al., 1991, O'Shea and Ortaldo, 1992, Cook and Splitter, 1989), is not restricted to the major histocompatibility complex (MHC), does not need previous sensitization, and is readily enhanced by interleukin-2 (IL-2) (O'Shea and Ortaldo, 1992, Henney et al., 1981). While NK cells remain difficult to define owing to the heterogeneous nature of their subpopulations, they have been characterized on the basis of their activity for several species including man (Hiserodt et al., 1982), dog (Knapp et al., 1993), cat (Tompkins et al., 1987), horse (Chong et al., 1992), cow (Cook and Splitter, 1989), swine (Salmon et al., 1989), mouse (Welsh et al., 1991), rat (de Jong et al., 1980, Lindsay and Allardyce, 1982), seal (Ross et al., 1996), hamster (Datta et al., 1979), guinea pig (Altman and Rapp, 1978), poultry (SieminskiBrodzina and Mashaly, 1991, Keller et al., 1992), and fish (Greenlee et al., 1991). NK activity has, until now, not been demonstrated in cetaceans.

Relatively high concentrations of environmental contaminants including PCBs and DDT have been measured in the tissues of many species of marine mammals from different parts of the world (Tanabe et al., 1983). The effects of these ubiquitous environmental contaminants on the health of these animals are still not well known. Numerous epizootics have recently been reported in marine mammals (Geraci et al., 1982, Domingo ct al., 1990, Osterhaus et al., 1988), and questions have arisen about the effects of the contaminants on the initiation and spread of these epizootics, possibly through immunosuppression. The importance of NK activity during the initial phase of viral infection (Welsh et al., 1991) as well as the demonstration of impaired NK activity in seals fed with contaminated fish (Ross et al., 1996) make this function particularly interesting. The possibility of deficient NK activity has also been suggested in St. Lawrence beluga whales to explain the large number of tumors observed in this isolated and highly polluted population (De Guise et al., 1994).

In the course of our studies to investigate the effects of environmental contaminants on health of marine mammals, we developed a series of assays to evaluate immune functions in cetaceans. In the present study, we describe quantitative assays to measure NK activity in beluga whales (Delphinapterus leucas) using two different methods: the ${ }^{5 !} \mathrm{Cr}$ assay and flow cytometry.

\section{Materials and methods}

\subsection{Animals}

Fresh blood from a captive beluga held at the Shedd Aquarium in Chicago, IL, USA, was used for a preliminary study on the technique, which was then applied to cryopreserved leucocytes from wild ranging belugas captured in August 1993 in the 
Churchill River estuary, Western Hudson Bay, Canada. The animal from Chicago was a male (Naluark) that also came from Churchill River. The wild animals were 5 males (2 adults, 3 immatures) and 3 females ( 2 adults, 1 immature). Pairs of belugas in which there were calves (young animals estimated to be younger than 2 yrs old) were not captured for sampling.

\subsection{Blood sampling and isolation of mononuclear cells}

Blood samples were drawn from the tail fluke (Chicago) or caudal peduncle (Churchill) into heparinized tubes (Vacutainer, Becton Dickinson, Rutherford, NJ. USA). The blood was kept cool until it was used: it was either shipped from Chicago to Bilthoven (National Institute of Public Health and Environmental Protection. The Netherlands) within $24 \mathrm{~h}$, or transported from the field study site on Hudson Bay to the laboratory at Churchill, where it was processed within three hours of collection. A complete blood count was performed for each animal to detect any individual abnormalities. For the evaluation of NK activity, blood was diluted in an equal volume of RPMI 1640 containing $10 \%$ fetal calf serum, $100 \mathrm{U} / \mathrm{ml}$ penicillin, and $100 \mu \mathrm{g} / \mathrm{ml}$ streptomycin (complete RPMI), and the peripheral blood mononuclear cells (PBMC) were isolated by density gradient centrifugation on Ficoll (specific gravity 1077, Pharmacia Biotech, Montréal, Qué.) for $35 \mathrm{~min}$ at $900 \times \mathrm{g}$. PBMC were resuspended in complete RPMI, washed three times, and viable cells enumerated using Trypan blue and light microscope or acridine orange and propidium iodide and fluorescence microscope. The cells were then used immediately or cryopreserved for further use (wild belugas).

\subsection{Cryopreservation}

For cryopreservation, cells were suspended at a concentration of $1 \times 10^{7} / \mathrm{ml}$ in fetal calf serum with 10\% DMSO, and aliquoted in cryogenic vials (Nalgene, Rochester, NY). The cell suspensions were frozen and stored in liquid nitrogen. For subsequent cell culture, the cells were thawed at $37^{\circ} \mathrm{C}$. and washed once and resuspended in complete RPMI.

\subsection{Target cell lines}

YAC-1, a murine lymphoma cell line, and K-562, a human erythroleukemic cell line, both generally recognized as NK sensitive, were used in the evaluation of NK activity. These cells were obtained from ATCC (Rockville, MD) and were cultured in complete RPMI at $37^{\circ} \mathrm{C}$ with $5 \% \mathrm{CO}_{2}$. The cells were passed at least once, $24 \mathrm{~h}$ prior to the assay.

\section{5. $\mathrm{Cr}$ release assay}

Both YAC-1 and K-562 cell lines were washed once in complete RPMI, and adjusted to $1 \times 10^{7} / \mathrm{ml}$. For labelling, $100 \mu \mathrm{l}$ of each target cell suspension $\left(1 \times 10^{6}\right.$ cells $)$ was incuhated for $45 \mathrm{~min}$ at $37^{\circ} \mathrm{C}$ with $100 \mu \mathrm{Ci}$ of ${ }^{51} \mathrm{Cr}$ (Amershaw International, Little Chalfont, Buckinghamshire, England). The cells were then washed 5 times with $10 \mathrm{ml}$ of 
complete RPMI, and resuspended in complete RPMI at a concentration of $1 \times 10^{5} / \mathrm{ml}$. Beluga whale PBMC were adjusted to $1 \times 10^{7} / \mathrm{ml}$ for an effector:target ratio of $100: 1$, $5 \times 10^{6} / \mathrm{ml}$ for an effector:target ratio of $50: 1$, and $2.5 \times 10^{6} / \mathrm{ml}$ for an effector:target ratio of 25:1. For each effector cell concentration, $100 \mu \mathrm{l}$ was plated in triplicate in round-bottomed 96-well plates for each target cell line (YAC-1 and K-562), and for each time of incubation ( 6 and $18 \mathrm{~h}$ ). For each target cell line (YAC-1 and K-562), and for each time of incubation ( 6 and $18 \mathrm{~h}$ ), $100 \mu \mathrm{l}$ of the $1 \times 10^{7} / \mathrm{ml}$ effector cell concentration was also plated in triplicate with $200 \mathrm{UI} / \mathrm{ml}$ of recombinant human interleukin-2 (rh-IL-2; EuroCetus, Amsterdam, The Netherlands). $100 \mu$ l of either ${ }^{51} \mathrm{Cr}$-labelled target cell line was added to the effector cells. For each time of incubation ( 6 and $18 \mathrm{~h}$ ), $100 \mu \mathrm{l}$ of either ${ }^{51} \mathrm{Cr}$-labelled target cell line was also added to 6 wells with $100 \mu \mathrm{l}$ of complete RPMI to assess spontaneous release, as well as to 6 wells with Triton $1 \%$ (Merck-Schuchard, München, Germany) to assess maximum release. The plates were then centrifuged at $200 \times \mathrm{g}$ for $1 \mathrm{~min}$, and cultured for 6 and $18 \mathrm{~h}$ respectively at $37^{\circ} \mathrm{C} 5 \% \mathrm{CO}_{2}$. The plates were then centrifuged at $200 \times g$ for $10 \mathrm{~min}$, and the supernatant from each well was transferred into counting vials, and counted 1 min in a gamma-counter. The triplicates (and the 6 samples for the spontaneous and maximal release) were averaged, and the specific release was calculated as follows:

$$
\frac{\text { experimental release }- \text { spontaneous release }}{\text { maximal release }- \text { spontaneous release }} \times 100 \%
$$

\subsection{Flow cytometric assay}

K-562 cells were used as target cells for a flow cytometric assay slightly modified from Chang et al. (1993). The target cells were washed once in complete RPMI, and adjusted to $1 \times 10^{6} / \mathrm{ml}$. One $\mathrm{ml}$ of the suspension was forcefully added to $10 \mu \mathrm{l}$ of a 3 $\mathrm{mM}$ solution of the lipophilic carbocyanine membrane dye 3,3'-dioctadecyloxarbocyanine perchlorate (DiO, Molecular Probes, Eugene, OR) dissolved in dimethyl sulfoxide (DMSO, Sigma, St. Louis, MO). The cells were then incubated for 20 min at $37^{\circ} \mathrm{C}$ in $5 \% \mathrm{CO}_{2}$, followed by 2 washes in complete RPMI. The cells were then resuspended in complete RPMI at a concentration of $1 \times 10^{5} / \mathrm{ml}$. Beluga whale PBMC were adjusted to $1 \times 10^{6} / \mathrm{ml}$, and $1000,500,250,125 \mu \mathrm{l}$ of the cell suspension were put in triplicate in $12 \times 75 \mathrm{~mm}$ polystyrene test tubes (Falcon, Mississauga, Ontario) for an effector:target ratio of $100: 1,50: 1,25: 1$, and 12.5:1 respectively. The volume in each tube was brought to $1 \mathrm{ml}$ with complete RPMI. One hundred $\mu \mathrm{l}$ of the labelled target cell suspension were then added to each tube, as well as to six tubes with $1 \mathrm{ml}$ of complete RPMI to assess spontaneous mortality. The tubes were centrifuged at $750 \times g$ for $30 \mathrm{~s}$, and placed at $37^{\circ} \mathrm{C}$ in $5 \% \mathrm{CO}_{2}$ for $150 \mathrm{~min}$. The tubes were centrifuged for 10 min at $250 \times g$, the supernatant was discarded, and the cells were resuspended in $300 \mu 1$ of a $200 \mu \mathrm{g} / \mathrm{ml}$ solution of ethidium bromide. The tubes were placed on ice and analyzed by flow cytometry using a FACScan (Bectun Dickinson). The beluga PBMC were distinguished from the K-562 target cells on the basis of their fluorescence at 530 $\mathrm{nm}$ (FL1), and were excluded from the acquisition using an electronic gate. The viability of the K-562 was assessed on the basis of their fluorescence at $630 \mathrm{~nm}$ (FL3). The 
triplicates were averaged, and the net $\mathrm{NK}$ activity was calculated as the difference between the mortality of the K-562 incubated with effector cells and the spontaneous mortality of the same cells (cultured without effector cells).

\subsection{Statistics}

The results are expressed as mean \pm standard deviation, and comparisons between groups were made using student $t$-test $(p=0.05)$.

\section{Results}

The ${ }^{5 /} \mathrm{Cr}$ assay revealed slight $\mathrm{NK}$ activity against $\mathrm{K}-562$ cells after $6 \mathrm{~h}(2.3 \%)$, but this activity was clearly enhanced in the presence of rh-IL-2 (16.8\%; Fig. 1). Nevertheless, this activity was proportional to the effector:target ratio with higher E:T ratios having the highest specific release. NK activity against YAC-1 cells after $6 \mathrm{~h}$ was detected only with the presence of rh-IL.-2, and was low $(2.0 \%$; Fig. 1$)$. After $18 \mathrm{~h}$. the NK activity against both cell lines was greatly increased, was proportional to the effector:target ratio against both cell lines, and was enhanced by the presence of rh-IL-2 (Fig. 2). The activity against K-562 was higher than that against YAC-1, except in the presence of rh-IL-2 after $18 \mathrm{~h}$ (Figs. 1 and 2). Spontaneous release after $6 \mathrm{~h}$ was relatively low $(14.9 \%$ and $10.4 \%$ of the maximal release for $\mathrm{YAC}-1$ and $\mathrm{K}-562$ respectively), while it was respectively moderately and slightly increased after $18 \mathrm{~h}$ for YAC- 1 and K-562 (39.3\% and $16.7 \%$ of the maximal release respectively).

The results of the flow cytometry-based assay demonstrated that K-562 could easily be discriminated from PBMC on the basis of their fluorescence at $530 \mathrm{~nm}$ (FL1) (Fig. 3), and that the distinction between live and dead K-562 was evident (Fig. 4). Average

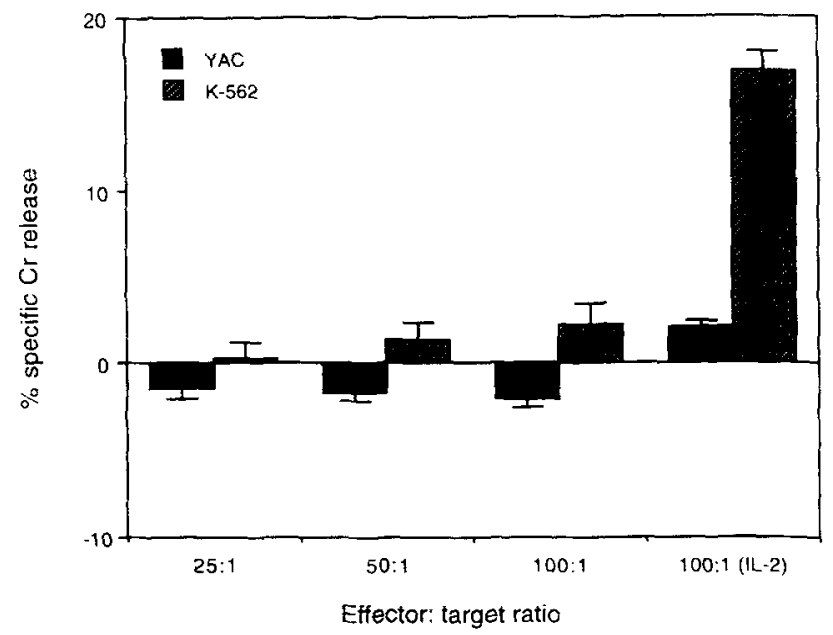

Fig. 1. Specific ${ }^{51} \mathrm{Cr}$ release in a beluga whale as an evaluation of $\mathrm{NK}$ activity after a 6-h incubation of PBMC with ${ }^{51} \mathrm{Cr}$ labelled YAC-1 and K-562 cell lines at different effector:target cell ratio, with or without IL-2. 


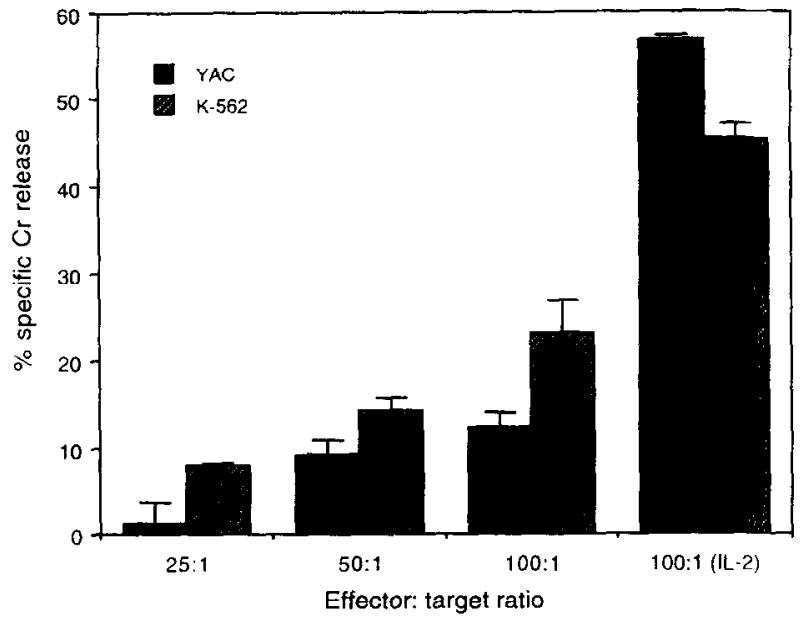

Fig. 2. Specific ${ }^{51} \mathrm{Cr}$ release in a beluga whale as an evaluation of NK activity after an 18 -h incubation of PBMC with ${ }^{51} \mathrm{Cr}$ labelled YAC-1 and K-562 cell lines at different effector:target cell ratio, with or without IL-2.
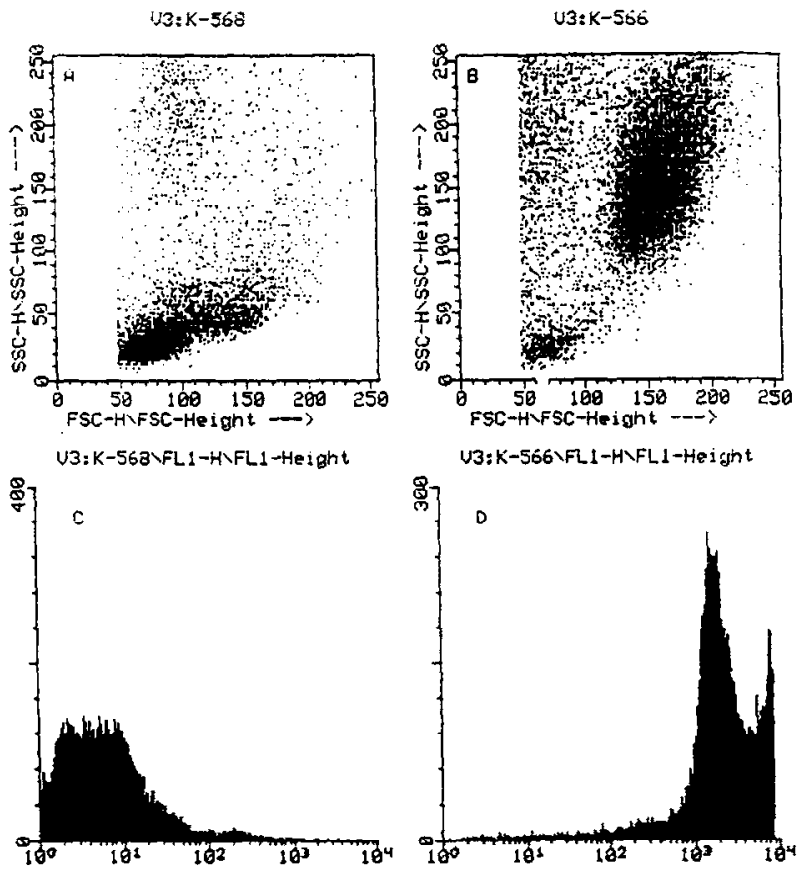

Fig. 3. The forward scatter (FSC) vs. side scatter (SSC) scattergram and corresponding fluorescence histogram at $530 \mathrm{~nm}$ (FL1) of unlabelled heluga PBMC (A, C) and of DiO-labelled K-562 (B, D) confirms the specificity of the staining for K-562 (larger cells) and not for PBMC. 


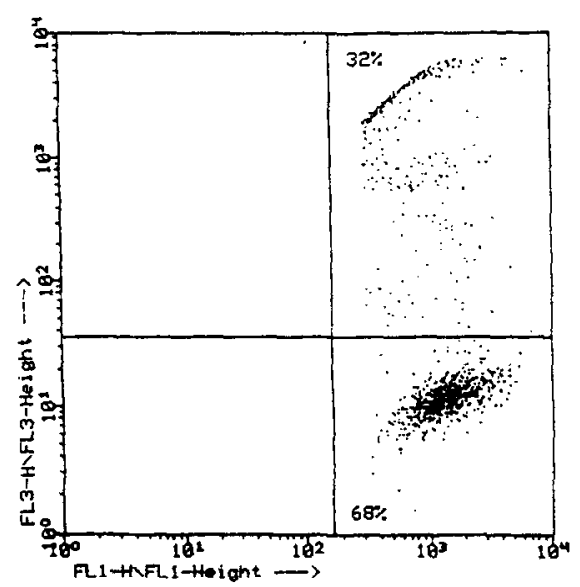

Fig. 4. The dual fluorescence scattergram (FLI vs. FL3) allowed to gate electronically on DiO-labelled K-562 according to their fluorescence (FLI) and shows the clear distinction between live and dead DiO-labelled K-562 cells according to the fluorescence (FL3) they did (dead cells) or did not (live cells) acquire upon exposure to ethidium bromide.

net NK activity in eight beluga whales against K-562 cell line was proportional to the effector:target ratio, with relatively small variations among the animals (Fig. 5). The NK activity of beluga whale PBMC against K-562 cell line at an effector:target ratio of $100: 1$ was $13.9 \% \pm 3.8 \%$ (range $9.9 \%$ to $17.8 \%$ ). The spontaneous death of the target cells (in culture without effector cells) remained relatively low $(11.6 \%$ ). At an E:T ratio of $100: 1$, there was no significant difference $(p>0.05)$ between males and females, nor between adult and immature animals.

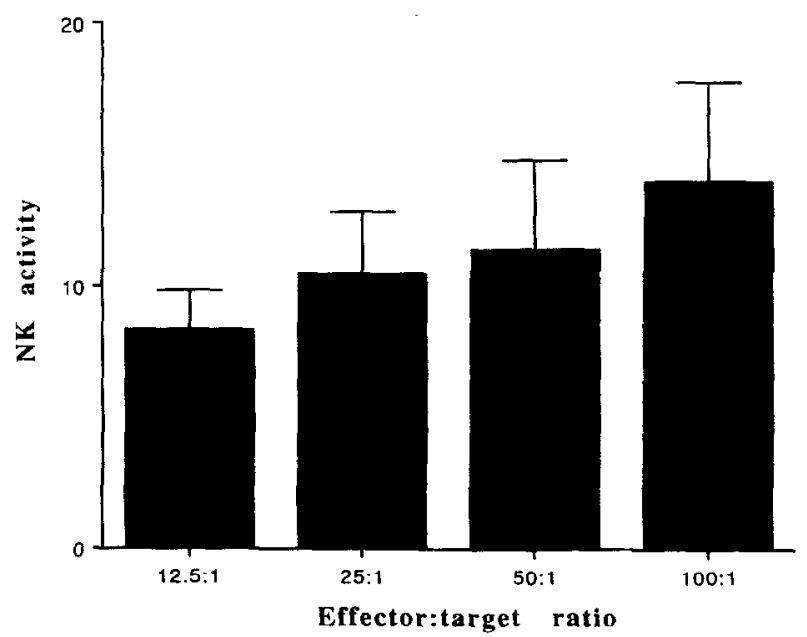

Fig. 5. Average NK activity in PBMC from eight beluga whales evaluated by flow cytometry as the percentage of dead K-562 for each effector:target cell ratio, from which spontaneous K-562 mortality was subtracted. 


\section{Discussion}

Our results here represent the first demonstration of NK activity in PBMC isolated from a cetacean species. This natural cytotoxicity was demonstrated against two established NK-sensitive tumor cell lines, the murine YAC-1 lymphoma, and the human K-562 erythroleukemia, and increased in direct proportion to the E:T ratio in culture. Since the activity without IL-2 was higher against K-562 than against YAC-1, K-562 were chosen for further experiments.

NK activity in beluga whales was enhanced with the presence of rh-IL-2. This shows the cross-reactivity of human IL-2 in the beluga, and is consistent with the IL-2 responsiveness observed in other species (Henney et al., 1981), including the harbor seal (Ross et al., 1996). The pattern of increasing cytotoxicity with increasing E:T ratios, the relatively high cytotoxicity against both YAC-1 and K-562 cell lines, and the IL-2 responsiveness of the $\mathrm{NK}$ activity suggest that the effector cells responsible for the NK activity in beluga whales have similar properties to natural killer cells for other species.

While the ${ }^{51} \mathrm{Cr}$ assay is a well-established test to assess NK activity in vitro, the problems associated with the manipulation of radioactive material might discourage its use in many circumstances. Numerous flow cytometric assays have been developed to assess NK activity without radioactive reagents. One method is based on the modification of the morphology of dead vs. live K-562 target cells (Vitale et al., 1989), while others used fluorochromes to evaluate either the mortality (Papa et al., 1988, Zarcone et al., 1986) or the viability (McGinnes et al., 1986, Shi et al., 1987, Chang et al., 1993) of target cells. Results have often been shown to parallel those of the classic ${ }^{51} \mathrm{Cr}$ assay (McGinnes et al., 1986, Zarcone et al., 1986, Shi et al., 1987, Papa et al., 1988, Chang et al., 1993). The method we chose (Chang et al., 1993) offers the advantage of being easy and efficient, while leading to reliable discrimination of target and effector cells, as well as the further assessment of the mortality in only target cells. While NK activity could be readily detected using both methods, the lack of radio-isotopes and related laboratory room make the flow cytometric method a viable and safe alternative. Using flow cytometry, NK activity was demonstrated in eight belugas with relatively small variations between individuals. The differences in levels of cytotoxicity between the two methods might be due to the differences in incubation times, which differ because of the difference in the events measured by the different assays. While flow cytometry measures the loss of membrane integrity that allows a dye to penetrate a cell, the ${ }^{51} \mathrm{Cr}$ assay measures the leak of a radioactive isotope from a cell after it has died and its membranes ruptured.

No significant differences were found between males and females, or between adult and immature animals in this study. This is in agreement with Lighthart et al. (1989) who found no difference in NK activity between young and aged humans on a per cell basis.

NK activity was demonstrated for the first time in a cetacean species, the beluga whale, in which it appeared similar to what is observed in other species. The evaluation of this function in cetaceans could lead to a better understanding of the early events that lead to viral epizootics in populations of marine mammals in different parts of the world, as well as the high prevalence of neoplasms in St. Lawrence beluga whales. 


\section{Acknowledgements}

The authors wish to acknowledge Dr. Jeff Boehm from Shedd Aquarium at Chicago for providing blood samples, and Jack Batstone and his team for help in the capture of belugas in Churchill. This project was funded by US Environmental Protection Agency, Canadian Wildlife Toxicology Fund, Environment Canada, World Wildlife Fund, Washington, Biodôme de Montréal, Corporation professionnelle des Médecins vétérinaires du Québec. SD is supported by a MRC scholarship.

\section{References}

Altman. A.. Rapp, H.J., 1978. Natural cell-mediated cytotoxicity in guinea pigs: properties and spec ficity of natural killer cells. J. Immunol. 121, 2244-2252.

Biron, C.A., Welsh, R.M., 1982. Activation and role of natural killer cells in virus infections. Med. Microbiol. Immunol. 170, 155-172.

Chang, L., Gusewitch, G.A., Chritton, D.B.W., Folz, J.C., Lebeck, L.K., Nehlsen-Cannarella, S.L., 1993. Rapid flow cytometric assay for the assessment of the natural killer cell activity. J. Immunol. Methods 166 $45-54$.

Chong, Y.C.. Duffus, W.P.H., Hannant, D.+ 1992. Natural killer cells in normal horses and specific-pathogenfree foals infected with equine herpesvirus. Vet. Immunol. Immunopathol. 33, 103-113.

Cook, C.G., Splitter, G.A., 1989. Comparison of bovine mononuclear cells with other species for cytolytic activity against virally-infected cells. Vet. Immunol. Immunopathol. 20, 239-261.

Datta. S.K., Gallagher. M.T., Trentin, J.J., 1979. Natural cell-mediated cytotoxicity in hamsters. Int. J. Cancer 23. $728-734$.

De Guise, S., Lagacé, A., Béland, P., 1994. Tumors in St. Lawrence beluga whales (Delphinapterus leucas). Vet. Pathol. 31, 444-449.

de Jong. W.H., Steerenberg, P.A., Ursem, P.S., Osterhaus, A.D.M.E., Vos, J.G., Ruitenberg. E.J., 1980. The athymic nude rat: III. Natural cell-mediated cytotoxicity. Clin. Immunol. Immunopathol. 17, 163-172.

Domingo. M., Ferrer. L., Pumarola, M., Marco. A., Plana. J., Kennedy. S., McAliskey, M.. 1990. Morbillivirus in dolphins. Nature $348,21$.

Geraci, J.R., St. Aubin, D.J., Barker, I.K., Webster, R.G., Hinshaw, V.S., Bean. W.J., Ruhnke. H.R.. Prescott, J.H.. Early, G., Baker, A.S., Madoff, S., Schooley, R.T., 1982. Mass mortality of harbor seals: pneumonia associated with influenza A virus. Science 215, 1129-1131.

Greenlee, A.R., Brown, R.A., Ristow. S.S., 1991. Nonspecific cytotoxic cells of rainbow trout (Oncorhynchus mykiss) kill YAC-1 targets by both necrotic and apoptotic mechanisms. Dev. Comp. Immunol. 15, $153-164$

Henney, C.S., Kuribayashi, K., Kern, D.E., Gillis, S.. 1981. Interleukin-2 augments natural killer cell activity. Nature 291, 335-338.

Hiserodt, J.C., Britvan. L.J., Targan. S.R., 1982. Characterization of the cytolytic reaction mechanism of the human natural killer (NK) lymphocyle: resolution into binding, programming, and killer-independent steps. J. Immunol. 129, 1782-1787.

Keller, L.H.. Lillehoj, H.S., Solnosky, J.M., 1992. JMV-1 stimulation of avian killer cell activity. Avian Pathol. 21, 239-250.

Knapp, D.W., Leibneitz, R.R., DeNicola, D.B., Turek, J.J., Teclaw, R., Shafer, L., Chan, T.C.K., 1943. Measurement of NK activity in effector cells purified from canine peripheral lymphocytes. Vet. Immunol. Immunopathol. 18, $433-442$.

Lighthart. G.J.. Schuit, H.R.E., Hijmans, W., 1989. Natural killer cell function is not diminished in the healthy aged and is proportional to the number of NK cells in the peripheral blood. Immunology 68, 396-402.

Lindsay, V.J., Allardyce. R.A., 1982. The natural killer system in the rat: the relationship between natural and immune cell-mediated lysis of fibroblast targets. Immunology 45, 423-430. 
McGinnes, K., Chapman, G., Marks, R., Penny, R., 1986. A fluorescence NK assay using flow cytometry. J. Immunol. Methods 86, 7-15.

O'Shea, J., Ortaldo, J.R., 1992. The biology of natural killer cells: insights into the molecular basis of function. In: Lewis, C.E., 'D McGee, J.O., (Eds.), The natural immune system: the natural killer cell, Oxford Univ. Press, New York. pp. 2-40.

Osterhaus, A.D.M.E., Groen, J., De Vries, P., Uyt de Haag. F.G.C.M., Klingeborn, B., Zamke, R., 1988. Canine Distemper virus in seals. Nature 335, 403-404.

Papa, S., Vitale, M., Mariani. A.R., Roda, P., Facchiani, A., Manzoli, F.A.. 1988. Natural killer function in flow cytometry: I. Evaluation of NK lytic activity on K562 cell line. J. Immunol. Methods 107. 73-78.

Ross, P.S., De Swart. R.L., Timmerman, H.H.. Vedder, L.J., van Loveren, H., Vos, J.G., Reijnders, P.J.H., Osterhaus, A.D.M.E., 1996. Suppression of natural killer cell activity in harbor seals ( Phoca vitulina) fed Baltic Sea herring. Aquatic Toxicol. 34, 71-84.

Salmon, H., Charley, B., Labonnardiere, C., Olivier, M., Kelley, K., Paraf, A., 1989. Natural killer (NK) activity and interferon (IFN) production by a fraction of spleen and blood lymphocytes in swine. Vet. Immunol. Immunopathol. 23, 113-128.

Shi, T.-S., Tong, M.J., Bohman, R., 1987. The application of flow cytometry in the study of natural killer cell cytotoxicity. Clin. Immunol. Immunopathol. 45, 356-365.

Sieminski-Brodzina, L.M., Mashaly, M.M., 1991. Characterization by scanning and transmission electron microscopy of avian peripheral blood mononuclear cells exhibiting natural killer-like (NK) activity. Dev. Comp. Immunol. 15, 181-188.

Tanabe, S., Mori, T., Tatsukawa, R., Miyazaki, N., 1983. Global pollution of marine mammals by PCBs, DDTs and HCHs (BHCs). Chemosphere 12, 1269-1275.

Tompkins, M.B., Ogilvie, G.K., Franklin, R.A., Kelley, K.W., Tompkins, W.A., 1987. Induction of IL-2 and lymphokine activated killer cells in the cat. Vet. Immunol. Immunopathol. 16, 1-10.

Vitale, M., Neri, L.M., Comani, S., Falcieri. E., Rizzoli, R., Rana, R., Papa, S., 1989. Natural killer function in flow cytometry: II. Evaluation of NK lytic activity by means of target cell morphological changes detected by right angle light scatter. J. Immunol. Methods 121, 115-120.

Welsh, R.M., Brubaker, J.O., Vargas-Cortes, M., O’Donnell, C.L., 1991. Natural killer (NK) cell response to virus infection with severe combined immunodeficiency. The stimulation of NK cells and the $\mathrm{NK}$ cell-dependent control of virus infections occur independently of $\mathrm{T}$ and B cell function. J. Exp. Med. 173, 1053-1063.

Zarcone, D., Tilden, A.B., Cloud, G., Friedman, H.M., Landay, A., Grossi, C.E., 1986. Fiow cylometric evaluation of cell-mediated cytotoxicity. J. Immunol. Methods 94, 247-255. 